\title{
Development of Chemistry Interactive Instructional Media Based on Mobile Learning on Oxidation-Reduction Reactions
}

\author{
Budi Kurniawan, Dedi Irwandi, Nanda Saridewi \\ Syarif Hidayatullah State Islamic University Jakarta, Jl. Ir. H. Djuanda 95, Ciputat, Indonesia \\ Corresponding e-mail: kurniawan2684@gmail.com
}

\begin{abstract}
This research aimed at developing chemistry interactive media based on mobile learning on oxidationreduction reaction and also at finding out the quality of the media that have developed. The instructional media developed by using Warsita models; design, production and evaluate. Products were validated by two expert lecturers and then examined by high school students of class X. Data of students' questionnaire responses from product trials obtained good category for ease of use navigation, cognitive load, knowledge space and information presentation, aesthetics and overall functionality. While for the media integration gets an excellent category. Then the results of teachers' questionnaire responses obtained good category for all aspect. Those results showed that instructional media chemistry interactive base mobile learning materials on reduction and oxidation reaction could be categorized as good.
\end{abstract}

Keywords: Instructional Media; Mobile Learning; Oxidation-Reduction; Reactions

\section{INTRODUCTION}

The development of information and communication technology in globalization is fast and useful for human life, and it can be felt in various aspects such as education.

$21^{\text {st }}$ century also known as the century of knowledge that will be the main foundation of all aspects of life (Rusman, 2013). Century of knowledge is century with complicated requirement and challenge.

Learning materials need a medium for delivery called instructional media. Instructional media are also useful for facilitating students in understanding learning materials. Munadi (2010) defines that instructional media are teaching message connector which creates planned by teacher or educator. Media is also everything that can deliver information from source to receiver such as video, tv, diagram, computer and teacher (Henich at al, 2002).

Smartphones are one of the communication technologies that can used in learning activities. According to Danim (2012) "the utilization of communication technology in learning activities are necessary, because it can make learning activities more effective and efficient". According to Uno and Nina (2010) "the developments of technology could increase various activity and productivity". One of the utilization of communication technology is a Chemistry Interactive Instructional media on oxidation-reduction reactions.

Students assume that oxidation-reduction reactions in chemistry materials are difficult, so it needs interesting instructional media. The solution is by using instructional media based on mobile learning. Mobile learning is a instructional media that uses handphone as a media (Listiyorini and Anteng, 2013).

Mobile learning is an instructional media that utilizes portable information and communication technology such as a smartphone, PDA, portable computer, etc. (Mcconatta et al, 2008). Floro (2011) defines "mobile learning as a learning that uses mobile technology devices, where learners do not have to be in a certain place". And according to Oller (2012), "mobile learning is a learning that is supported by technology devices such as mobile 
phones, laptops and PDA". Besides that, mobile learning should have specifications such as spontaneity, portable, blended, private, interactive (Ozdamli and Cavur, 2011). Mobile learning can make learning materials more attractive, and mobile learning also can be accessed anytime and anywhere (Ally, 2009).

Instructional media based on mobile learning is a media that is in line with technological development. Mobile learning is also make an educational process become more flexible and meet the needs of longlife learning (Georgiev at al, 2004). Besides that, this media not much developed, so it can be a new innovation in educational media.

\section{METHOD}

This research was held on June 2015, in two different schools; State of Senior High School 4 (SMAN 4) Tangerang Selatan and private Senior High School Dua Mei (SMA Dua Mei) Ciputat. This research aimed to get a response to instructional media that was made. Population of the research was all of students and teachers in SMAN 4 Tangerang Selatan and SMA Dua Mei Ciputat, and sample was all of the class X students' Natural Science in those schools.

The research method used were ADDIE and Warsita's phase which consists of 3 phases: (1) Design, (2) Producion (3) Evaluation (Warsita, 2008).

The data were collected by using observation sheet and questionnaire. Collected data through the observation sheet was analysed by summing up the number of checklist $(\sqrt{ })$ in every column in observation sheet from each indicator that had been made and counting by converting raw data into percentage and determining category for each sub of indicator based on ability scale as in Table 1 showed (Ridwan, 2012). Questionnaire was used for assessing instructional media. Instructional media assessed by instructional media expert and chemistry materials expert based on indicators interactive multimedia used by Thorn in his research which consists of 6 indicators: (1) Ease of use and navigation, (2) Cognitive load, (3) Knowledge space and information presentation, (4) Media Integration, (5) Aesthetics, (6) Overall functionality (Thorn, 1995).

\begin{tabular}{ccc}
\multicolumn{3}{c}{ Table 1 Score Interval } \\
\hline No. & Score & Category \\
& Interval & \\
\hline 1. & $81-100 \%$ & Very Good \\
2. & $61-80 \%$ & Good \\
3. & $41-60 \%$ & Adequate \\
4. & $21-40 \%$ & Insufficient \\
5. & $0-20 \%$ & Very \\
& & Insufficient \\
\hline
\end{tabular}

\section{RESULT AND DISCUSSION}

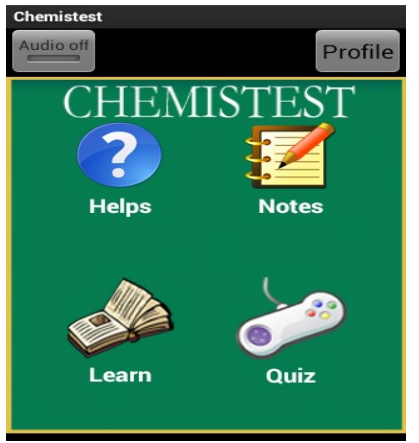

Figure 1. The Product of Instructional Media.

The product of instructional media in this research showed in Figure 1. This product assessed by instructional media expert and chemistry materials expert using questionnaire. According to validity test by Instructional media expert, there was found invalid aspect in Ease of use and navigation indicator because there's no cancel or back button in quiz menu so the in instructional media must be fixed. The result before and after fixed can show in Figure 2.

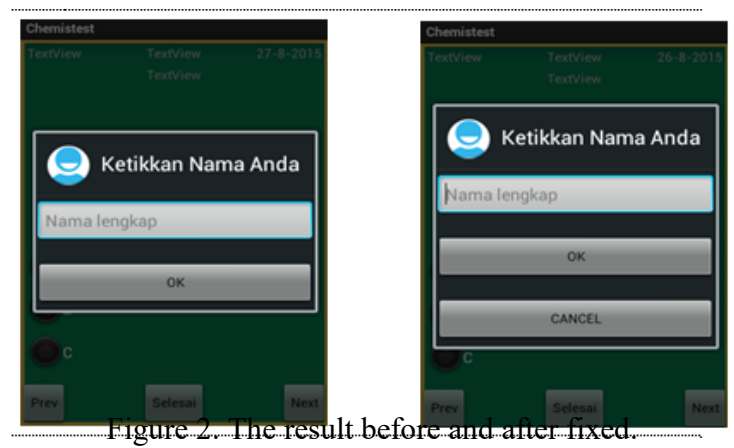

The validator also provides suggestions for the development of this instructional media such as: (1) about developer profile and institute (2) animation in chemistry materials (3) make a random question in quiz menu. 
According to validity test by chemistry materials expert, there is no invalid aspect in all indicator. But the validator provides suggestions to ensure the content of the material has a reference, so there is a change in the profile menu as in Figure 3.
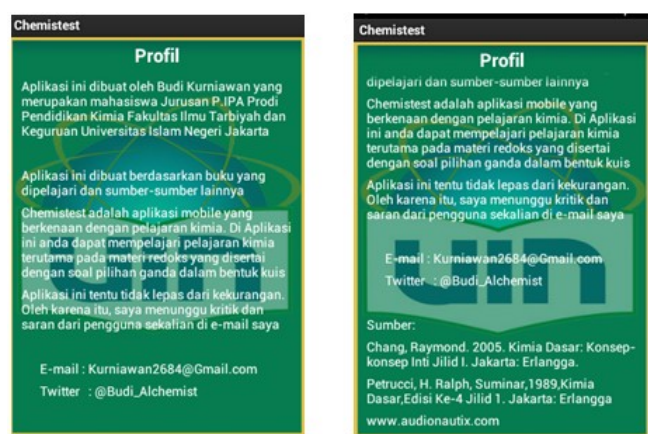

Figure 3. Before and after validator suggest.

Suggestions provided by validators make this instructional media has advantages from another instructional media such as Romiyatun's instructional media (2012). There is no explained about a cognitive domain in question quiz. While in this research, instructional media have cognitive domain $\mathrm{C} 1-\mathrm{C} 4$ and validated by chemistry materials expert.

Instructional media in this research also has advantages from Gunawan's instructional media (2014). Gunawan's instructional media only have three multiple choice and not random. In this research, instructional media have five multiple choice and random. So every students gets the different question. Overall, this instructional media can used in learning activities.

The result of instructional media from students response (Figure 4) obtained good category in all indicator except media integration. Media integration indicator obtained $83 \%$ (very good category). It shows that instructional media in this research help students to improve their skills in applying media for learning. According to Dale in Arsyad (2014) "instructional media has a function to helps students in their experience in the learning process".

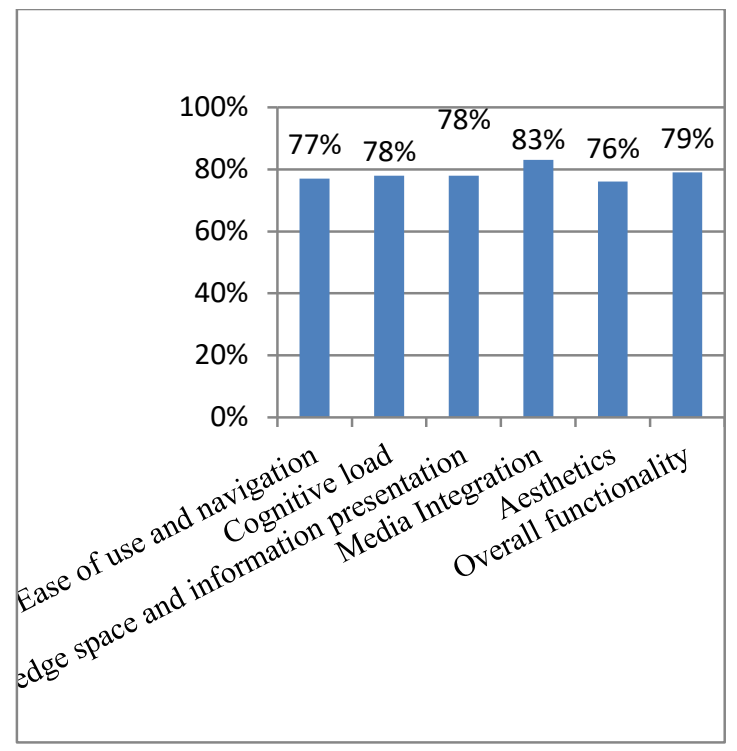

Figure 4. The Result of Students Response.

The result of Instructional media from teachers response (Figure 5) obtained good category in all indicator. Ease of use and navigation indicator obtained highest score $(80 \%)$, and aesthetics obtained the lowest score (73\%). According to the result from teachers responses, the instructional media in this research was easy to use and not required any special skill.

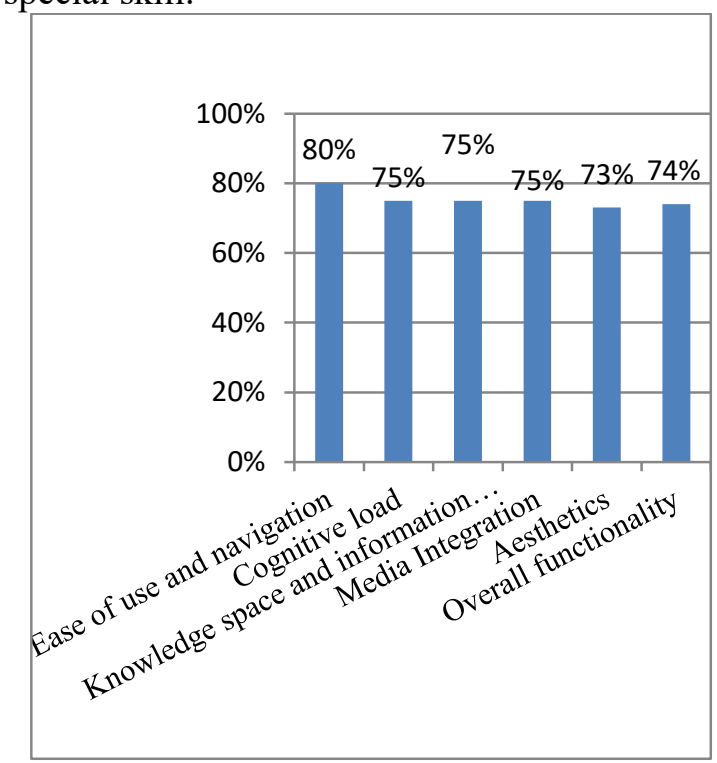

Figure 5. Result of Teachers Responses.

According to the result form students and teachers response, instructional media in this research obtained good category. It means the 
instructional media in this research can used in a learning activity. Besides that, the instructional media also helps students in studying individual or group and make students more focused in learning (Kaur and Manpreet, 2013)

\section{CONCLUSIONS}

The research showed that development of chemistry interactive instructional media based on mobile learning on oxidation-reduction reactions obtained good response based on to students and teachers.

\section{REFERENCES}

Ally, M. (2009). Mobile Learning Transforming the Delivery of Education and Training. Atabasca University: AU Press.

Arsyad, A. (2011). Media Pembelajaran. Jakarta: PT. Raja Grafindo Persada.

Danim, S. (2010). Media Komunikasi Pendidikan. Jakarta: Bumi Aksara.

Floro, N. (2011). Infoline Tips Tools and Intelligence for Trainers : Mobile Learning. Amerika: ASTD Press.

Georgiev, T., Evgenia, G., \& Angel, S. (2004). M-Learning - a New Stage of E-Learning. International Conference on Computer Systems and TechnologiesCompSysTech, . 4(28), 1-5.

Gunawan, I. (2014). Pengembangan Aplikasi Mobile Learning Fisika Sebagai Media Pembelajaran Pendukung. Jurnal Pendidikan Fisika Fakultas Tarbiyah dan Keguruan IAIN Raden Intan Lampung, 3(1), 1-7.

Heinich, R., Molenda, M., Russel, J.D., \& Smaldino, S.E. (2005). Instructional Technology and Media for Learning Seventh Edition. New Jersey: Pearson Merrill Prentice Hall.

Kaur, A., \& Bhullar, M.S. (2013). A New Method of Learning: M-Learning (Mobile Learning). Proceedings of the World Congress on Engineering and Computer Science, 1, 187-189.

Listyorini, T., \& Widodo, A. (2013). Perancangan Mobile Learning Mata Kuliah Sistem Operasi Berbasis Android. Jurnal SIMETRIS, 3(1), 25-30.

Mcconatha, D., Praul, M., \& Lynch, M.J. (2008). Mobile Learning in Higher Education: An Empirical Assessment Of A new educational Too. The Turkish Online Journal of Educational Technology, 7(3), 1.

Munadi, Y. (2010). Media Pembelajaran Sebuah Pendekatan Baru. Ciputat: Gaung Persada press.

Oller, R. (2012). The Future of Mobile Learning. Louisville: Educase center for Applied Reasearch.
Ridwan \& Sunarto. (2012). Pengantar Stastistika untuk Peneletian: Pendidikan, Sosial, Komunikasi, Ekonomi dan Bisnis. Bandung : Alfabet. Cet. V.

Romiyatun, D.A., Ikhsan, J., \& Sari, L.P. (2012). Pengembangan Mobile Game "Brainchemist" Sebagai Media Pembelajaran Kimia Sma/Ma Pada Materi Teori Atom Mekanika Kuantum, Ikatan Kimia Dan Termokimia. Jurnal Pendidikan Kimia FMIPA Universitas Negeri Yogyakarta, 1(2), 1-9.

Rusman. (2013). Belajar dan Pembelajaran Berbasis Komputer. Bandung: Alfabeta.

Sanjaya, W. (2008). Perencanaan dan Desain Sistem Pembelajaran. Jakarta: kencana.

Thorn, W.J. (1995). Points to Consider when Evaluating Interactive Multimedia. The Internet TESL Journal, 2(4), 1.

Uno, H.B., \& Lamatenggo, N. (2010). Teknologi Komunikasi \& Informasi Pembelajaran. Jakarta: Bumi Aksara.

Warsita, B. (2008). Teknologi Pembelajaran Landasan \& Aplikasinya. Jakarta : Rineka Cipta. 